\section{UK stops short of outright smoking ban in enclosed public places}

Kaye McIntosh London

The UK government has stopped short of banning smoking in all enclosed public places. Detailed proposals unveiled this week will still allow smoking in pubs and clubs that don't serve chilled or hot food.

The minister for public health, Caroline Flint, admitted that doctors would be "disappointed" by the failure to introduce an outright ban on smoking in enclosed public places. But she added: "Clearly there are people in the medical profession who would prefer an outright ban, but when we undertook consultation as part of the Choosing Health white paper it was clear that people felt government should act but that there should be exceptions, as smoking is legal."

She defended the proposals, saying: "When the legislation is on the statute book we will have $99 \%$ of workplaces smoke free [and] most public places smoke free, with a few exceptions."

Government research showed that just $20 \%$ of people favour an outright ban in pubs, she added. Pubs and clubs serving food, shopping centres, betting shops, and train and bus stations will be covered by the ban.

But a BMA report published in May, Booze, Fags, and Food, estimated that in some areas $80 \%$ of pubs do not serve food and could still allow smoking after the ban comes into force in 2008. In the prime minister's own constituency, Sedgefield in County Durham, a third of pubs do not serve food.

Ms Flint admitted that between $10 \%$ and $30 \%$ of licensed premises nationally would be exempt from the ban. "We need to look at health inequalities. It is a question we have to ask ourselves about why our health communication is not being taken up by some communities," she said.

The BMA's deputy chairman, Sam Everington, said: "The arguments about the effects of secondhand smoke have been won, and the government accepts this. Given it is acknowledged that secondhand smoke kills, the lives and health of employees must be the priority."

"It should not matter where an employee works. Whether someone works in an office or a non-food pub, they have a right to have their health protected at work," he continued.

Patients in psychiatric units and hospitals and hospices for adults will still be allowed to smoke, despite the government's pledge to achieve a smoke-free NHS by 2006.
The proposals, which go out to consultation until 5 September, will shape elements of the Health Improvement and Protection Bill. Smokers will face fines of $£ 50$, while managers of premises that fail to prevent smoking could be fined up to $£ 200$ under the proposals.

The ban will come into force by 2007 for most enclosed public places and 2008 for pubs and clubs, except those not serving food.

Ireland already has a ban on smoking in all pubs and bars, while Scotland is planning a ban next year.

FOREST, which supports smokers' freedom, has criticised the proposed ban in England. Its director, Simon Clarke, said: "Punitive legislation is unwelcome and unnecessary and would infringe the rights of thousands of people, including publicans and restaurateurs." $\square$

See www.dh.gov.uk/

Consultations/LiveConsultations

\section{Indian government bans smoking in new films and TV serials}

Ganapati Mudur New Delhi

After weeks of debate over a proposal from the health ministry, the Indian government has decided to ban the portrayal of smoking in new films. Consumer groups and doctors have welcomed the move.

The ban on the portrayal of smoking or other uses of tobacco, announced by the information and broadcasting ministry last week, will apply to films and television serials produced after 2 October 2005.

Citing studies of how films influence attitudes to tobacco among young people, the health ministry had originally proposed a ban on the use of tobacco in all films and television serials.

But the government has decided that the use of tobacco will be banned only in new productions. Cinemas playing old films will need to display on their screens statutory warnings about the harmful effects of tobacco.

It has also ruled that television channels will have to scroll statutory warnings across screens each time the use of tobacco is shown in a serial.

"We're happy the government has recognised the seriousness of the problem and decided to act," said Mr Bejon Misra, chairman of the Consumer Coordination Council, a coalition of consumer groups.

Legislation passed last year prohibits smoking in public places and bans direct and indirect advertisements of tobacco products. But consumer groups have expressed concern that tobacco companies are using films to promote tobacco and even brands.

India has an estimated 250 million tobacco users, but just $14 \%$ use cigarettes. The rest smoke unfiltered "bidis" or chew tobacco.

The Indian Council of Medical Research has estimated that 800000 people die from causes related to tobacco consumption each year and has been urging policy initiatives to curb consumption.

Two years ago a study for the World Health Organization of 335 films produced in India between 1991 and 2002 found that $76 \%$ had scenes depicting the use of tobacco. Smoking by "good guys" in films had increased from $22 \%$ in 1991 to $53 \%$ in 2002, and tobacco brand names were clearly visible in some scenes, the study found.

One film maker interviewed for the study said that his company had turned down tobacco companies that had approached it. "But there are needy producers who would do anything for money," he was quoted as saying.

Film makers have decried the ban, saying it will impinge on their creative freedom. But doc-

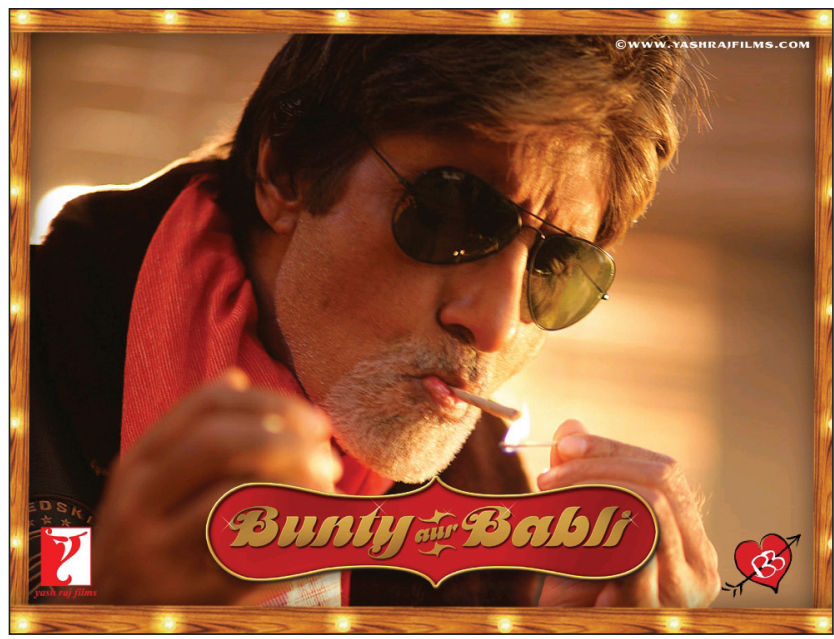

The actor Amitabh Bachchan, who plays the eccentric policeman Dashrath Singh in Bunty Aur Babli, has a passion for smoking bidis consumption by characters is not critical to storylines.

"A talented director or actor doesn't need a cigarette to depict a debonair hero, a menacing villain, or a liberated woman," said Dr K Srinath Reddy, head of cardiology at the All India Institute of Medical Sciences and Indian representative at the Framework Convention for Tobacco Control.

"Much remains undone," said Mr Misra. "Pictorial warnings, including skulls, on packets are mandatory by law but haven't been enforced yet." tors have argued that tobacco 